\title{
Beyond the Cataclysm: Cultural Nationalism in McCarthy's The Road and Hamid's The Reluctant Fundamentalist
}

\author{
https://doi.org/10.33806/ijaes2000.20.2.10 \\ Soha El Samad \\ Lebanese University, Lebanon
}

\begin{abstract}
Despite the realization that cultures are essentially "hybrid and heterogeneous," the aftermath of 9/11 saw the bulk of literature re-instating the cultural divide between East and West. This paper compares the futuristic vision in Cormac McCarthy's The Road and Mohsen Hamid's The Reluctant Fundamentalist to reveal humanity's regression into a 'survival of the fittest' state from a dual Western and Eastern view. This reading therefore provides a cultural perspective involving a methodology that includes theorists and researchers in the field in order to illustrate the extent to which one can validate the culture to which one belongs. It also contributes to the debate over the role of religion and culture in acquiring a sense of nationalism.
\end{abstract}

Keywords: culture, ethical, fundamentalism, identity, nationalism, reinscription

\section{Introduction}

One fundamental consequence of the 9/11 attacks on American industrial and cultural icons was a return of the hitherto forgotten, overlooked or repressed self/other dichotomy. Seeing that the conception of America as the sovereign, hegemonic nation faltered following this catastrophe, many individuals, groups and institutions entered a state of anxiety as they struggled to restore this broken image. Basing his argument on relevant research and compiled data, Eric Lichtblau (2016: para.1) confirms that this condition has had negative repercussions with "Hate crimes against American Muslims...soar[ing] to their highest levels since the aftermath of the Sept. 11, 2001 attacks." Consequently, the result was an atmosphere of general hostility and a solid cultural divide which provoked further violence. Inspired by the events on that fateful day, the two novels in this study, Cormac McCarthy's The Road and Mohsen Hamid's The Reluctant Fundamentalist, offer two different perspectives yet not absolutely different reactions to this catastrophic event, and invite a re-evaluation of cultural hybridity and cultural nationalism.

For the most part, both novels' "efforts to tell of things that have been lost" (Walsh, 2009: 268) portray the traumatizing experience of loss, confusion, and melancholy following the apocalypse. Certainly it is through reclaiming national and individual identity that such painful and damaging repercussions can be quelled. In which case, whether victim or victimizer, each person or group would react accordingly. This reaction, known as national re-inscription, is according to 
Frederic Jameson (2002: 298) strengthened through "media hype, and the subsequent media patriotism" intended to trigger a renewed interest in past glories and thus revive or rebuild a nation's historical or cultural past. Accordingly, the 9/11 attacks created such an urgent need for America to re-claim its imperious existence to the extent that it turned into "a nation of people who decided that their world view would combine agendas for individual freedom and mechanisms for devastating racial oppression" (Morrison 1993: xiii). Reacting against such an essentialist stance, Butler (2006:40) firmly asserts,

... the notion of the world itself as a sovereign entitlement of the United States must be given up, lost, and mourned, as narcissistic and grandiose fantasies must be lost and mourned. [...] Unfortunately, the opposite reaction seems to be the case.

This study therefore attempts to discern and understand the defensive reactions of individuals who appear to live in a multicultural world but who instinctively and openly resort to re-establishing a dualistic ideological stance when their cultural history or national identity is openly threatened. Recent years have witnessed intercultural relations relapsing into closer systems that employ racist and religious ideologies as the main nationalist directives while conducting their transnational affairs. The problematic therefore is the extent to which cultural inscription can reclaim identities undergoing a traumatic experience. Furthermore, if culture and ethics prove to be instinctive recourses for those experiencing a sense of loss, then the development of national identity on such a basis can be an effective replacement for the more precarious path of religious and racially motivated extremism. In other words, the presumption is that when nationalism is based on the moral, humane and cultural, it is bound to foster and promote a more tolerant intercultural outlook toward Others. In which case, a close reading of the chosen novels can shed light on the above issues while contributing to ongoing studies on nationalism. However, it should be stressed at the outset that though the reactions of the protagonists in both novels are culturally resilient, the underlying sense of pride in their willingness to transfer their cultural heritage in dire circumstances invites positive impact. Consequently, a healthier intercultural atmosphere is bound to develop in the long-run.

As early as 1983, Benedict Anderson argued that nations are imagined communities that developed from "the convergence of capitalism and print technology on the fatal diversity of human language" (46). Likewise, his contemporary Ernest Gellner (1983) considers nationalism an artificial political construct and draws attention to the unanticipated "strength of nationalism" that is based on enhanced religious beliefs aimed at promoting an essentialist Arab nationalism. A few years later, 9/11 confirmed Gellner's (1983:6) views and his definition of a nation as "not an inherent attribute of humanity ... Two men are of the same nation if and only if they share the same culture, where culture in turn means a system of ideas and signs and associations and ways of behaving and communicating" (see Anderson 1983:12-13). Religion's hegemonic power is therefore deemed undeniable with D.C. Mulder (1985:35) placing emphasis on the 
role of religion as an expression of human culture and Pascal Boyer (2001:47) further postulating religion as unquestionably one of the most influential cultural components. In a sense, 9/11 also gives credence to Rudolf Rocker's (1993:13) assertion "that before men can be driven to war they must be lashed into a certain pitch of passion and by the further fact that this passion can only be aroused by spiritual and moral motives." On the other hand, Bruce Lincoln (2000:416) conceives aesthetics and ethics as major elements of culture and does not give religion a central role thereby affirming that the ethical and the moral can be performed from a humane stance instead of a religious one. Moreover, though Rocker (1993:18) highlights the sole power of a nation's religion, he also maintains its influence on culture stating that cultural nationalism is essentially reactionary revealing "the interrelationship of nationalistic ideology with the creed of every revealed religion" (Ibid:144). On the other hand, David Miller advocates the ethical over the religious and even over the individual dictates of genetics or heredity in determining cultural standards (1995:21-27). In light of such debates, Edward Said's (1979) declaration that cultures are "hybrid and heterogeneous" and Stuart Hall's assertion that culture is never homogenous (Hall 1976: 39) appear idealist since they highlight the need for transcultural and intercultural relations in a global world where extreme nationalist thought has become a firmly rooted and instinctive human trait as manifested by the ongoing cycles of violence in the world. With respect to the chosen narratives which have "come to dominate public discourse ... [since] they serve most effectively to give definition to in-group identity and values through reference to an out-group" (Funk\&Said 2004:3), their very production is expressive of the need to communicate the self to an Other. In fact, the protagonists' eagerness to articulate their cultural traits does not suggest a clash of civilizations resulting from what Samuel Huntington (1996) refers to as the resurgence of "indigenization," nor does it lend credence to Fukuyama's assertion "that humans will reestablish some foundation for identity and purpose, even when that means plunging back into conflict and History, with a capital Hegelian 'H'" (Miller 2019). To be more precise, cultural heritage is the safest anchorage by which each protagonist strives to survive and reclaim his individuality with apparently no deliberate harmful intent.

\section{Mourning and denial in The Road}

To begin with, one cannot but notice the insistence to re-inscribe cultural memory in McCarthy's novel. The Road's unanticipated and undefined apocalyptic event with its cold, gray, polluted aftermath, portrays man's latent fear of the unknown and the anxiety of losing one's national identity. McCarthy's reputation as a "novelist of the American West" situates his narrative within "the scorched wasteland of a post-apocalyptic America" (Ibarrola-armendariz 2011:2). As such, it is an American ordeal where "circumstances compel them to go through some of the rites of passage that are the staple of Western fiction and movies" (Ibarrolaarmendariz 2011:9). In his first televised interview with Oprah Winfrey, McCarthy (2007) admitted to having been inspired by the September 11 attacks, 
and attributed the novel's wide reception to the fear of the apocalypse stating that "since 9/11 peoples' emotions were concerned about apocalyptic issues, we're not used to that." He added that there would have been no story were it not for his seven-year old son, sixty-six years his junior, who was about two years old at the time of the attacks. As an older parent concerned for his son's future safety, this event must have weighed heavily upon the author's mind.

There are two factors to consider when discussing McCarthy's sense of loss in The Road. First, it is a novel of mourning; of nostalgia for a generation facing extinction in an oppressively dismal atmosphere. Secondly, the fact that the author or narrator cannot specify or name the catastrophic event indicates a state of denial triggered by the traumatic incident. Cathy Caruth (1995: 151) explains that in such a state, though "the images of traumatic reenactment remain absolutely accurate and precise, they are largely inaccessible to conscious recall and enactment." She further elucidates that "the trauma seems to evoke the difficult truth of a history that is constituted by the very incomprehensibility of its occurrence" (1995: 153). As such, it is an event beyond the ability of an imperial nation, which has always prided itself with its indestructibility, to come to terms with or to grasp. Jacques Derrida (2003:86) aptly describes the immediate effect of the aftermath of 9/11 on an individual's psyche:

... the place and meaning of this "event," remains ineffable, like an intuition without concept, like a unicity with no generality on the horizon or with no horizon at all, out of range for a language that admits its powerlessness and so is reduced to pronouncing mechanically a date, repeating it endlessly, as a kind of ritual incantation, a conjuring poem, a journalistic litany or rhetorical refrain that admits to not knowing what it's talking about.

More importantly, the immensity of the event has been taken advantage of in order to reinforce America's imperialist role. From a Foucauldian perspective, the two numbers, 9/11, enter discourse as an unforgettable memory that grants America the right to wage a "war on terror" and thus reinforce its imperialist role (Sheth 2011). What presides is therefore the idea that America is protecting itself and others from the standpoint of the victim and "the good Samaritan." Hence, the apocalyptic dimensions of 9/11 have generated both denial and remembrance with "each impl[ying] the other: they are inextricably entwined" (Edkins 2003: 16). Consider for instance the man's statement in The Road: "You forget what you want to remember and you remember what you want to forget" (McCarthy 2006:12) which is immediately and prominently given credence in his confession of a memorable "long forgotten" moment after 9/11. It is a moment he desperately urges himself to hold on to by affirming that he must "Make a list. Recite a litany. Remember" (McCarthy 2006:31). Furthermore, the ritualistic and repetitive manner in which he describes their food and eating habits, their use of the tarp as a table, their choice of dessert, is a desperate attempt to cling to what is left of a "dying world" (ibid., 18) where "the sacred idiom [is] shorn of its referents and so of its reality" (ibid., 89). It is important to highlight that these recollections and 
memories are not intended for vengeful purposes but to preserve his cultural reserves in an effort to reclaim his identity. In such moments, it is not religious teachings that prod the narrator on, but the instinct to survive internally and externally/psychologically and physically. In such a desperate state, the "litany" is not a prayer or an invocation to God, but a hymn intended to preserve memories of cultural items; it is necessary that they reiterate the names of simple, immediately present, stale signifiers as it is all they are left with to survive.

One way in which McCarthy emphasizes his claim to his nation is by dedicating his novel to his son in order to leave him a concrete written legacy that emphasizes only those events he wants to impress on his son's memory. In his turn, as a projection of the writer, the father is also protective and selective when he urges his son not to look at the horrible sights so they will not be implanted in his memory. In addition, he tends to be overtly melodramatic in his concern for his son's mental and physical safety out of a sense of profound responsibility. Enclosing the events within a specific historical context, serves McCarthy's purpose. Another significant method the author uses is distancing; throughout the narrative he highlights the father and the son's isolation within the borders of their native land while keeping the 'Other' beyond the margin; firmly outside the narrative space. It is only the man and the boy who have the privilege to be on the American "state" road that runs throughout the narrative.

Like all trauma victims, the narrator resorts to an essentialist attitude, a sort of "indigenization," a cultural nostalgia that together with survival tactics, includes beliefs that vary from those of traditional religion. His aggressive denial of God, of religion as a whole, is typical of trauma victims while his subversion of traditional religious beliefs agrees with Bruce Lincoln's (2000: 410) argument that societies can construct religion. In this case, it is one based on morality as the only true religion and on his existence as the Supreme Being entitled to launch his son as the future prophet of a declining humanity. The boy, as a role-model of pure innocence and goodness, is above humanity; in his father's opinion, if he is "not the word of God God never spoke" (McCarthy 2006:5) This is the kind of "Religious feeling [that] has assumed political forms [so that] the political man today confronts the natural man just as antagonistically as did the man of past centuries who was held in the grip of the church's dogmatism" (Rocker, 1995: 173). It should be noted that the overwhelming sense of nostalgia and mourning running through the narrative can be attributed to the narrator's awareness of his impending death - the reason why he takes it upon himself to carry the burden of responsibility in order to ensure the well-being of his race through his son.

The narrator thus becomes a free soul and acquires "a conscience that looks death in the face... [and reveals a] link between the care of the being-towarddeath... and freedom that is responsibility" (Derrida, 2003: p.17). From this privileged position, he is independent of all religious dogma; he is free to play the part of god and determine the spiritual and mental direction of his nation. This would explain his subversion or distortion of religious beliefs. The first perceptible religious image or allegory to be misrepresented is that which associates the man to Abraham on the road to Mount Moriah to sacrifice his son. 
Though the narrator is initially willing to sacrifice the boy should they be threatened, he later confesses that his "job" is to take care of him, to keep him alive, since he "was appointed to do that by God" (McCarthy 2006:77). In a way, it is the man who sacrifices himself for the safety of his son, for him to "carry the fire" (ibid. 278), and more importantly to keep a part of himself, his identity and culture, alive in the "unimaginable future" (ibid. 273). Accordingly Rocker (1993: 49) affirms, "The individual dies, but never society. States perish, cultures only change their scene of action and forms of expression."

The second religious allegory is that which recalls the parable of the Good Samaritan. However, unlike the biblical story which focuses on help coming to poor helpless strangers from an unexpected compassionate source, the man acts coldly and unsympathetically toward the miserable, helpless strangers. It is thus that he instinctively contradicts the image of the "good guys" he is building for himself but his son fares better. Upon encountering the first decrepit stranger, the father refuses to offer any help much to his son's discontent who urges him to reconsider his actions and show compassion in a manner typical of a "carrier of the light." Later, when they encounter the second old, haggard, and dirty stranger on the road, the narrator is once again obliged by his son to offer some food. It is interesting to note that this repetitive emphasis on the boy's inherent goodness occurs within a closed narrative space symbolic of the place, the heritage the father assertively holds on to. In a sense, the narrator/author is placing the fate of mankind upon the survival of these two lone travelers, especially the boy as the future healer of humanity. In a sense, the man is still strictly egoistic in his cultural persistence and the good, innocent boy might fare better in assimilating and connecting with others.

\section{Language, intertextuality and cultural memories}

Another survival technique intended to maintain and transfer cultural memory is carried out by the protagonist through speech or language and is in line with McCarthy's novelistic tradition which harbors nostalgia for the American West. The Road can therefore be considered "the culmination of his legacy of remythologizing the American West" (Ibarrola 2007:10). The narrator's language reflects a desperate attempt to recall and preserve memories that have become insignificant in such an aftermath. Typical of a trauma narrative, the narrator's conception of reality and memory is somehow vague or distorted and the only manner in which he can express meaning rests in the use of signs that immediately point to their stale referents. According to Kristjan Mavri (2013:6),

In a world unhinged by overwhelming destruction, the possibility of a unified representation through the language of the old order is impaired significantly. Not only is language unable to encapsulate the traumatic experience of the demise of nature and civilization, but so much of what language once signified is in fact lost.

On the other hand, Mavri (2013:8) asserts that "however bleak and transmogrified, [language] is productive of meaning." Accordingly, what is not 
completely lost in McCarthy's language, is its attempt to reconstruct the national self. The most significant indication of discursive nationalization is the fact that where both protagonists are unnamed, the titular road is possessively determined by the man as "our roads... the state roads" (43). The possessive adjective indicates an obsessive assertiveness - the desire both to own and to belong to the last surviving and most enduring part of his culture. The narrator later identifies one real life location which is Rock City in Georgia. Interestingly, Ibarrola (2011:4) remarks that the novel practically has "no landmarks to indicate what region of the country the pair are traveling in" and "one cannot be sure if [Rock City] is a real town or just a sardonic wink on the part of the author suggesting that the whole world has been deprived of life and turned into stone." Whatever the case might be, McCarthy has hit two birds with one stone since his narrator has taken pains to nostalgically assert that the overall location or setting is 'the road' running through the grey, cold, apocalyptic 'states'. Such an exaggerated assertiveness results in a dual response, especially among non-American readers. In the first place, it is natural to identify with the universal human fear of the end of existence, but in the second place, there is a lack of identification with this nightmarish setting where cultural essentialism and distancing is the main stance running throughout.

Apart from biblical allusions, subtle intertextual expressions also harbor an undercurrent of nationalist discourse. The nice, smiling veteran "of old skirmishes" (McCarthy 2006:281) and the affectionate, almost nostalgic discourse in which he is portrayed, conjures the image of a typically American soldierly presence, as done by the "good guys" with whom the boy finally resides. Furthermore, the incident where both protagonists come across a group of "bad guys' wearing red scarves around their necks is associated with communism and favors the dominant cultural and political attitude toward communism since the red scarf is symbolic of communist China. This is another traumatic experience, a reminder of past days of glory that are no more. When once his country was superior and dominant, it no longer is the case. He is now in hiding; a prey to these marching predators.

Moreover, the narrator's desperate desire to transport his son to a safe environment, where the "good guys" reside, points to both an individual and national fear of being constrained by an Other 'evil' power. Notice for instance the second traveler's words "There is no God and we are his prophets" (my italics, McCarthy 2006:170). The sentence holds a close syntactic structure or a similar word pattern to the Islamic statement of faith, known as "shahadah." However, intense denial in the first part and ardent assertion in the second with the substitution of the prophet's name for ' $w e$ ' shifts the reference from the specific to the general. This statement suggests an atheistic stance that attempts to include all of humanity. Since the image of the boy as a messenger or as a prophet has previously been established, as has the narrator's denial of God, the tramp's statement seems a desperate plea for ethical conduct - for the ethical and the moral to guide humanity. The subjective plural would therefore refer to every survivor in the wasteland and expressively subvert all religious beliefs. Yet 
another subtle intertextual element can be discerned in the narrator's description of the boy's existence as part of "All things of grace and beauty..." (54). This renders the boy a culturally accepted privilege since the syntactic and semantic pattern brings to mind the popular American children's hymn "All things bright and beautiful." This intertext enhances the boy's prophetic image and is further strengthened when his golden hair is placed in the spotlight as a "golden chalice, good to house a god" (75).

Most importantly, the man struggles to preserve as much of his cultural past as possible and realizes that he cannot "enkindle in the heart of the child what was ashes in his own" (McCarthy 2006: 154). Language fails in making him recapture the past, "He tried to think of something to say but he could not... Colors... Names of birds" (McCarthy 2006: 88/89), and stories of past glories become meaningless with the boy complaining "in the stories we're always helping people and we don't" (McCarthy 2006: 268). Yet, in his state of self-reliance and search for life's bare necessities he succeeds in directly evoking national memory through remnants of nature and most importantly through the food culture. The paraphernalia of cultural objects, material goods, and different varieties of food are a real and direct "representation of that which defies forgetting. This leads the reader to invoke spatial identity and memory even when the narrative claims that " "[t]here is nothing to see"" (Mavri, 2013:8).

As important as the boy is in his role as the carrier of the light is the grocery cart as the carrier of culture. It accompanies the protagonists throughout the narrative and is protected as much as the boy is. In less than a week after disposing of the cart, the narrator passes away leaving the boy with cherished memories most of which are related to the food culture, to American cuisine and eating habits. One significant cultural icon mentioned twice is that of the CocaCola drink. The narrator introduces it to his son as a "treat," and "lean[s]his nose to the slight fizz coming from the can" (McCarthy 2006:23) relishing its sparkles before handing it to the boy. As Kristjan Mavri (2013:9) illustrates, "for the man and the reader it fizzes with nostalgic reminiscence... invoking and inverting such Coca- Cola slogans as 'America's favorite moment'." In this context, it is relevant to mention Benjamin R. Barber's (1995:6-186) "dialectic of McWorld" in which he deems "the logic of McWorld... [as] as far more likely to bring with it the vices of the West (its cultural imagery and the ideology of consumption as well as a 'logical' tolerance for social injustice and inequality" and is thus a foil to Jihadism or tribal/ethnic fundamentalism. The second time father and son have the same drink, the Coca-Cola image is already firmly ingrained in his son's memory. The incident where the man and the boy come upon the underground shelter adorned with "the richness of a vanished world" (McCarthy 2006:139) with "crate upon crate of canned goods" (ibid. 132) serves as the climax of the narrative since it is here that they exist in an in-between state between forgetting and remembering. In this small, fully-equipped shelter they spend a few days in a state of suspension of belief where they ignore the ugly reality of the outside world. Jenny Edkins (2003:16) elucidates that "some forms of remembering can be seen as a way of 
forgetting: Ways of recovering from trauma by putting its lessons to one side, refusing to acknowledge that anything has changed, restoring the pretence."

As an allegory, the novel harbors an underlying moral reinforced by its overwhelming nostalgia and sentimentality. It highlights man's propensity for acting morally while harmlessly preserving and protecting one's national culture. It also briefly acknowledges the existence of an Other who, though living beyond the border, is similar and yet not different from them. Towards the end, the father reminisces on his son's suggestion of the possibility of their being a father and his son out there, remarking that "perhaps beyond those shrouded swells another man did walk with another child on the dead gray sands" (McCarthy 2006:219). Consequently, though the novel is chiefly concerned with what Vamik Volkan (1998:4) describes as a chosen traumatic incident, or "the mental representation of an event that has caused a large group to face drastic losses, feel helpless and victimized by another group, and share a humiliating injury," it appeals to the most affective and humane of plights - that of a father and his son; hardly a few paragraphs go by without the narrator expressing overt fatherly affection and protectiveness. According to Ibarrola (2011:9),

... in order to appreciate the true literary stature of The Road one should put aside all considerations related to historical and geographical spaces and concentrate, instead, on what the novel has to offer in terms of examples of paternal-filial love, knowledge of one's environment, and the incidence of individual existences on the larger collective history and narrative of a community.

Thus, in spite of the novel's isolation within nationalistic border lines, the fact that it foregrounds human morality serves to "provide the very link between cultures" (Caruth, 1995:11). What survives after the man's death is a sense of national identity acquired through the "good" community the boy is taken to, and those special memories between a father and his son which by their very nature point to a particular culture. In this sense, the narrative supports Miller's view that "Nations are ethical communities. In acknowledging a national identity, I am also acknowledging that I owe special obligations to fellow members of my nation which I do not owe to other human beings" (Miller 1995, 49). As a post-modern allegory, The Road is a reminder of the nightmarish consequences of a humanity gone wrong. With an open-endedness imbued with a sense of hope, a new beginning, and the coming of a generation with a positive moral outlook, the novel justifies Peter Messent's opinion of a fiction that expresses "the type of universal and fundamental mythic resonance which takes [readers] beyond such national cultural boundaries, and gives them an epic quality that transcends their 'Western' roots" (Ibarrola 2011:6).

\section{Cultural vanity in The Reluctant Fundamentalist}

From the East, the voice of the marginalized Other comes to take precedence in Mohsen Hamid's novella which offers a different cultural perspective that nevertheless follows a similar path of cultural revival to that of The Road. In one of the most original of narrative techniques, Hamid's protagonist intricately 
weaves his cultural memories with a predominantly sarcastic, mocking, and critical tone befitting the essentialist aim of his dramatic monologue; a single narrator whose monologue or point-of-view directs readers is in itself a dualistic, 'othering' mechanism designed to subvert the already established power structure in which America occupied the centre. The novel boasts a sense of cultural pride as a response to the racist attacks triggered by an apocalyptic event identical to that of McCarthy's text. According to Peter Morey (2011:135), The Reluctant Fundamentalist, "challenges the orthodoxies of the post-9/11 novel that ... had generally taken the form of documents of personal trauma or loss, or recapitulations of unproblematic notions of essential cultural difference" (135). Changez, a Pakistani who studied at Princeton University and worked for Underwood Samsun relates his personal experience of the impact of the devastation to an unnamed American he meets in a café in his hometown, Lahore. It is his voice that dominates the narrative while the American is merely voiced through the narrator's comments. Just as Changez loses his space in New York following the attacks, so does the American lose his narrative space in unfamiliar territory. In effect, Changez's reaction mirrors that of Americans whose sense of community or nationalism is re-ignited in a desperate attempt to reclaim their reputation as citizens of an unconquerable world power. With the attacks looming over America as unforgettable proof of its vulnerability, Changez hyperbolically describes how American flags invaded New York "to proclaim: We are America ... the mightiest civilization the world has ever known; you have slighted us; beware our wrath" (Hamid 2007:90). Such a deterioration of the relationship between East and West demonstrates, according to Bradley Freeman (2011: 2) that the "threatening specter of the East continues to haunt the US with territorial dissolution. September $11 \ldots$ epitomized this threat in that it reveals the deceptive Eastern Other bent on America destruction." Interestingly, just as McCarthy's man and boy occupy the center of an American setting, Hamid's Changez is at the center of a Pakistani one.

Changez's return to Pakistan is therefore a retaliatory move against his oppressive victimization. He is answering back to American nationalism in an almost vengeful tone that heightens the latter's sense of insecurity. The American becomes the unwanted, marginalized Other, upon whom Changez vents his feelings of alienation and insecurity: "an animal that has ventured too far from its lair and is now, in unfamiliar surroundings, uncertain whether it is predator or prey!" (Hamid 2007:35). Changez's dialectic of belonging and not belonging becomes pronounced and psychologically disturbing to the extent that he decides to leave America to 'stop' this feeling of alienation. He also explains that his "unwilling[ness] to reflect upon the shared pain that united you with those who attacked you" (Hamid 2007:190) is a two-way experience. In this way, he echoes Frederic Jameson's (2002) belief in the denial of identification with trauma victims, especially those who institute collective blame and retaliate by inflicting collective traumatic oppression. The aftermath of 9/11 follows the same principle of "an eye for an eye" carried out by McCarthy's protagonist, the boy's father, 
when he mercilessly takes away all the thief's clothing. Changez's psychological ordeal therefore results from his being suddenly transformed into an exile in his host country. This is resolved after his encounter with Juan-Bautista who enlightens him to the cold hearted, objective nature of a job whose "focus on the fundamentals" juxtaposes the fundamentalism attributed to the East against that of the West. It is the kind of fundamentalism that reflects the American, capitalist way of life and its obsession for material benefits regardless of the harm caused to others. After leaving his job, his uncertain sense of belonging (Hamid 2007:168) abates and is replaced by a renewed awareness of his culture's and nation's worth. He becomes a fundamentally Pakistani citizen proud of his inherited culture. Hence, his trauma before leaving America is basically two-fold: it is one of selfreproach and shame at having had to identify with a discriminatory culture and imperial power in a diasporic condition Bharati Mukherjee (1996:29) describes as traumatic with America being the site of the "drama of self-transformation," and secondly, his distress at becoming a stranger, an unwelcome immigrant who gloats at others' misfortune. The former is expressed in his shame and humiliation after taking on the role of Chris to please Erica (America) while the latter materializes in a spontaneous smile while watching the catastrophic explosions.

\section{Cultural heritage and Reinscription}

Just as McCarthy's narrator resorts to transferring cultural attributes through extensive information to his son, so does Hamid's protagonist presenting a meticulous and detailed conversational transfer of his cultural heritage to a bewildered foreign listener. His novella distinguishes the egocentric, hungry America symbolized by a personified Princeton that "raised her skirt for the corporate recruiters" (Hamid 2007:5), from Changez's hospitality and generosity which prevail as typical attributes of Pakistanis. Nathan Funk and Abdul-Aziz Said (2004:20) have elaborated on the East/West dichotomy and their increasingly dualistic cultural relationship stating that,

... a "clash of symbols" is being waged between Islam and

the West: Westerners are finding headscarves, turbans and other

symbols of Islamic religious expression repellent; similarly

fundamentalist Muslims see blue jeans and other manifestations

of Western culture as explicit anti-Islamic statements.

In his narrative Changez answers back to Western ethnocentricity by elevating his culture to a high nationalist plane. He creates a space through which he reasserts the historical and cultural significance of his country in juxtaposition with America that has always strived on the duality between East and West, with East representing Islam. That is, Hamid's narrative functions as a counterdiscourse or a writing-back to the episteme that confronts American post-9/11 fiction and their "determination to look back" (ibid., 131) to their days of glory, with real historical facts about his nation's glory; where "Lahore, the second largest city of Pakistan, ancient capital of the Punjab, home to nearly as many people as New York, layered like a sedimentary plain with the accreted history of invaders from the Aryans to the Mongols to the British" (ibid., 8). Furthermore, 
the American dream is as fake as the Gothic buildings of Princeton that are made to look older "through acid treatment and ingenious stonemasonry" (ibid., 3) since for them "in history...it is the thrust of one's narrative that counts, not the accuracy of one's details" (ibid., 135). He addresses stereotyping by remembering the time he was mistaken for an Arab on account of his beard, and mockingly answers back to this experience by telling the American that he recognized him by his "bearing" and not by the generally acknowledged fair Western coloring since they too "have a range of complexions in this country" (ibid., 1). Upon learning that the American has travelled to the East, he expresses mock surprise, sarcastically stating, "Truly, you are well-travelled for an American" (ibid., 73). He proudly explains their propensity to drink fine tea and with loud, proud enthusiasm remembers the once prosperous Pakistan:

We built the Royal Mosque and the Shalimar Gardens in this city, and we built the Lahore Fort with its mighty walls and wide ramp for out battleelephants. And we did these things when your country was still a collection of thirteen small colonies, gnawing away at the edge of a continent. (Hamid 2007: 116)

Furthermore, he conceitedly introduces the respectful manner of addressing the elderly in Urdu, elaborates upon "Lahori Cuisine" (ibid., 114) and eating habits. He assumes a threatening tone in his reference to "predatory delicacies" and his declaration that "There is great satisfaction to be had in touching one's prey" (140). In effect, since he realizes that the man intends to kill him in his own country, he is trying to gain the upper hand through those brief suggestive remarks; probably, by getting to know more about his culture, the American might have second thoughts. He goes on to describe traditional furniture, Jasmine flower necklaces, "a tradition of shared rituals of mysticism" (ibid, 159), an old saying (ibid., 163), the smell of the desert (ibid.,176), generosity (ibid.,183), his final goodbye to Erica "as one twirls rupees above the living" (ibid., 191), and the traditional naming of buildings (ibid., 193). Most importantly, he justifies his 'smile' at the unfortunate catastrophe comparing it to the American nonchalant attitude stating, "it is hateful to hear one person gloat over one's country's misfortune. But surely you cannot be completely innocent of such feelings yourself" (ibd.,84). Moreover, Changez demonstrates what Edward Said refers to as a "contrapuntal consciousness," a form of intertextuality in which he refers to aspects of American culture when he compares Erica to Paltrow and Spears, refers to movies like "Grease," American "popcorn shrimp" and compares the flirtingact from Pakistani and American perspectives.

The narrative is essentially an attempt at cultural re-inscription and a critique of American nationalism and stereotyping. The future has been significantly shattered by the apocalyptic dimension of the attacks leaving signs of bleak expectations for humanity. Initially, all characters seem to suffer from traumatic nostalgia, a lost irretrievable past, and an unwanted and unexpected change accompanied by the sense of overhanging doom. When Hamid/Changez smiles on hearing the devastating news, he justifies this heartless reaction as 
humane as it results from his ironic awareness of the "symbolism of it all" (83) and renders it. In effect, his attitude provides empirical evidence of Frederic Jameson's (2002) belief that a collective sharing of a particular nation's misfortune does not exist. Similarly, a look at the allegorical or symbolic signification of the novel's names helps illustrate the essence of the nationalist bent. First of all, Erica's deceased lover Chris symbolizes both a lost religion and an "Old World appeal" (Hamid 2007:30). Secondly, Erica represents a gradually deteriorating America in her relationship with other cultures, or other peoples, while Underwood Samsun's initials are suggestive of the US as is the name "Sam." Finally, Changez's name is suggestive of change or a psychological recovery and development following a traumatic experience; a change initiated from within and not forced upon him by a nation which adopts a condescending attitude toward all others expecting them to conform to its culture out of the need for financial stability. Notice, how in his first interview, Jim comments upon Changez having a "hungry" (ibid., 13) countenance; a statement Changez defies towards the end stating that he "had always resented the manner in which America conducted itself in the world" (ibid., 177).

It is possible to trace the relationship between East and West through Changez's relationship with Erica. In his attempt to regain Erica or America's favor, he briefly takes on the role of Chris and for the second time is overcome by shame (the first being the time when he adopted a strictly New York identity in Manila). There is no mention of a specific religion but the presence of both Christianity and Islam hangs over the narrative and 'haunts' the text in much the same manner as Chris haunts Erica. Erica insists on remaining distant from Changez in spite of her attraction to him, to the extent that each meeting with her results in a further "spacing out" (98). Even while attempting to place his hand in close proximity to hers, in one of her most vulnerable states, she pulls hers away (Hamid 2007: 127/128) since the specter of Chris always calls her back. It is no surprise therefore that Changez describes Erica's and Chris's love as a bond, "a religion that would not accept [him] as a convert" (ibid., 129). Erica comes to symbolize an America suffering from "the trauma of an attack on her city" (ibid., 129) and is unable to deal with the present, to accept Changez into her life in spite of the fact that each feels at home in the other's abode. In a state of "chronic nostalgia" (168), she resorts to past glories and memories to maintain her stability or existence until she escapes or disappears in what is suspected as suicide. On their last meeting, Changez compares her thin frail body to one who has been fasting (ibid., 152). Such an exaggerated cross-cultural comparison reflects his desperation to pull Erica closer to his traditional religion in an attempt to unite his cultural background to that of a lost world. In the end, her escape is typical of trauma victims who go to extremes to protect themselves from possible danger. Derrida's (2003: 98) description of the traumatic effects of that particular event (September 11) can best explain Erica' psychological state; she is one,

... traumatized not in the present or from the memory of what will have been a past present. No, traumatized from the unpresentable future, from 
the open threat of an aggression capable one day of striking? For you never know? The head of the sovereign nation-state par excellence.

For Changez, Erica's published book is an anti-climax. It does not reveal anything about her condition, her troubled mind and leaves him as uncertain about her as always. Though each had felt a sense of belonging and homeliness in the other's abode, those occasions become distant memories and an impossible reality. David Gay explains (2011:68) Erica's “inaccessibility in her fictional narrative, [as] an isolated fantasy [which] parallels, on the level of allegory her name implies, the inaccessibility of America as a future home for Changez in the wake of 9/11." The fact that Changez decides to leave after his realization that "power comes from becoming change" (Hamid 2007:110) indicates a healthier state of mind than that of his American counterparts. However, his inability to forget Erica, to continue hoping to meet her, suggests a trace of longing for that brief past he had enjoyed in luxury and tranquility. It can also harbor some faint hope of future understanding and an intercultural dialogue.

\section{Conclusion}

It appears that though religion hovers like a ghost above both narratives, it is intentionally ignored as an essential component of cultural inscription. The emphasis is on dual cultures that focus on traditional habits and morals or basic human principles of conduct for creating a nation. Moreover, though the title of Hamid's novel insinuates religious fanaticism, especially in a novel published in the aftermath of 9/11, what it entails is a subversion of the East/West binaries and a re-centralization of the East to expose the immorality of America's material fundamentalism. Consequently, America is placed under the limelight as practicing a form of McWorld fundamentalism in its unethical approaches to business and international affairs. At bottom, both east and west are similar in their fundamentalist obsessions in so far as fundamentalism reveals "the manifestation of l'idée fixe - the fixed idea." (Mirus: 2011). In which case a fundamentalist or blind support for a fixed idea or belief is not different from a nationalist sense that is, according to John Breuilly (1993:1) "above and beyond all else, about politics and that politics is about power." Thus, the concept of fundamentalism is given a broader scope of reference to include Western power games such as "the concept of American interests in the guise of the fight against terrorism" (Hamid 2007: 203). What is also significant is the lack of direct religious reference within the contextual framework of Hamid's narrative. It can be argued that religion is intentionally marginalized for the purpose of foregrounding culture. Notice that even when Changez and the American withdraw from the warmly lit atmosphere of the café unto the street in an atmosphere of heightened suspense, Changez reassuringly remarks, "but you should not imagine that we Pakistanis are potential terrorists, just as we should not imagine that you Americans are all undercover assassins" (208/209) and explains his political and not his religious stance with respect to Pakistani and 
American politics. In this sense, Changez answers back to American isolationist, nationalist prejudice with an isolationist, nationalist attitude.

With respect to The Road, its nationalist tone tends to keep Eastern readers at a geographical, cultural and mental distance from circumstances or events which they logically assume to be strictly American. Cultural dualism is strengthened in a manner that coincides with Christina Cavedon's (2015) argument that,

...the collective does not claim the traumatic experience of the victims because the American resilience template does not allow for an identification with them. Rather, this template revolves around the conviction that although a traumatic event poses challenges to the subject that experiences it, the experience eventually produces the idea of a rupture within history (personal and collective) which offers the possibility of a fresh start. (149-150)

However, on a more general level, the man's plight represents that of everyman's irrespective of culture, race or religion. Thus, both postmodern novels, while harboring a nostalgia for the past, advocate a reinscription of cultural memories, a return to the past, as a means of preserving identity and alleviating what is considered as man's primal fear of the unknown. Interestingly, while religion's cultural aspect appears to be more pronounced in McCarthy's novel, both protagonists largely portray a harmless nostalgic attachment to their individual cultures. Though it cannot be denied that the novels harbor parallel depressing atmospheres, their open-endedness unlocks a sense of hope for humanity to connect on an individual level. To end on a more optimistic note, it remains up to readers to recognize the beauty of cultural diversity and aspire for an existence built on positive human interaction. For instance, readers can follow the trajectory of reluctance and reassurance in Hamid's voice at the end of his narrative to arrive at a conclusion that suggests a non-violent ending. Similarly, it can be argued that the American's presence, even as a passive listener to Changez's detailed cultural descriptions and information, is in itself meaningful. As for McCarthy's novel, the father's gaze unto the horizon suggests an inherent desire to connect to other races or peoples regardless of distance or difference while the good boy's survival is a sign of hope.

Finally, as narratives reflecting their respective cultural spaces, both novels belong to the tradition of narration whose "universality" according to Majed Aladaylah, "exceeds the borders of infinite knowledge...to achieve total transformation between individual and culture, and negates ambivalences between cultures and social identities" (2018:169). Thus, narratives can pave the way for the development of a sound cultural identity in tandem with the humane and moral. Besides, identifying with other cultures on such a solid basis can result in hybrid identities befitting the present age of globalization. To conclude, further research into the relationship of nationalism to religion, morality, and culture can help uncover paths towards a healthy intercultural and humane existence in a world where nationalism has become essentialist and a cause of strained intercultural relations. 
Soha El Samad

Department of English Language and Literature

Lebanese University

Email: soha.elsamad@ul.edu.lbcom

\section{References}

Aladaylah, Majed. (2018). "Negotiating Narrative in Transcultural Spaces by Leila Aboulela's Minaret." International Journal of Arabic-English Studies (IJAES,) 18:169-175.

Anderson, Benedict. (1983). Imagined Communities: Reflections on the Origin and Spread of Nationalism. London: Verso.

Barber, Benjamin. (1995). Jihad Vs. McWorld. New York: Random House Publishing.

Boyer, P. (2001). Religion Explained. New York: Basic Books.

Breuilly, John. (1993). Nationalism and the Sate. Great Britain: Manchester UP.

Butler, Judith. (2006). Precarious Life: The Powers of Mourning and Violence. London \& New York: Verso.

Caruth, Cathy. (1995). "Trauma and Experience: Introduction.” Trauma: Explorations in Memory. Ed. Cathy Caruth. Baltimore: Johns Hopkins UP, 3-12.

Cavedon, Christina. (2015). Cultural Melancholia: US Trauma Discourses Before and After 9/11. Leiden, Netherlands: Brill Publishers.

Derrida, Jacques. (2003). "Auto immunity: Real and Symbolic Suicides," a dialogue published in Philosophy in a Time of Terror: Dialogues with Jurgen Habermas and Jacques Derrida. London: The University of Chicago Press.

Edkins, Jenny. (2003). Trauma and the Memory of Politics. Cambridge: Cambridge UP.

Eric Lichtblau. (2016). "Hate Crimes Against American Muslims Most Since Post-9/11 Era." The New York Times. Sept. 17, 2016.

Freeman, B. M. (2011). Threatening "the Good Order": West Meets East in Cecil B. DeMille's The Cheat and John Updike's Terrorist. Journal of Transnational American Studies, 3 (2). Retrieved from https://escholarship.org/uc/item/6p306627

Frederic Jameson. (2002). "The Dialectics of Disaster," The South Atlantic Quarterly 101.2: 297-298. ProjectMUSE. University of Zagreb, Faculty of Philosophy. Retrieved April 11, 2018 from http://muse.jhu.edu/

Funk C. Nathan and Abdul Aziz Said. (2004). "Islam and the West: Narratives of Conflict and Conflict Transformation." International Journal of Peace Studies, Volume 9, Number 1, Spring/Summer 2004: 1-28 
Gay, David. (2011). "Confronting Myths of Difference: Fundamentalism, Religion and Globalization in Mohsin Hamid's The Reluctant Fundamentalist." Religious Studies and Theology 30.1. pp. 57-70.

Gellner, Ernest. (1983). Nations and Nationalism. Oxford: Blackwell.

Hall, Stuart; T. Jefferson. (1976). Resistance Through Rituals. Youth Subcultures in Post-War Britain. London: Harper Collins.

Hamid, Mohsen. (2007). The Reluctant Fundamentalist. Great Britain: Penguin Books.

Huntington, Samuel P. (1996). The Clash of Civilizations and the Remaking of World Order, pp.368, New York: Simon \& Schuster.

Ibarrola-Armendariz, Aitor. (2011). "Cormac McCarthy's The Road: Rewriting the Myth of the American West." European journal of American studies, vol.6 (3): pp. 1-14. Accessed September 11, 2018, from https://doi.org/10.4000/ejas.9310

Lavedon, Christina. (2015). Cultural Melancholia: US Trauma Discourses Before and After 9/11. Netherlands: Brill | Rodopi.

Lincoln, Bruce. (2000). 'Culture', in W. Braun \& R.T. McCutcheon (eds.), Guide to the study of religion, pp. 409 - 421, London: Cassell.

Mavri, Kristjan. (2013). "Cormac McCarthy's The Road Revisited: Memory and Language in Post-Apocalyptic Fiction." Politics of Memory. No. 2 - Year 3- LC.2

McCarthy, Cormac. (2006). The Road. New York: Vintage Books. (2007). "Oprah's Exclusive Interview with Cormac McCarthy." June 2007. Retrieved December 1, 2019 from OPRAH.COM.

Miller, David. (1995). On Nationality. Oxford: Clarendon Press.

Miller, Paul. (2019). "Fukuyama Was Right (Mostly)." The American Interest. Jan 14. Retrieved April 10, 2019 from <https://www.the-americaninterest.com/2019/01/14/fukuyama-was-right-mostly/>

Mirus, Jeff. (2011). "Fundamentalism and the Abandonment of Reason." Retrieved April 11, 2019, from https://www.catholicculture.org/commentary/articles.cf m?id=510

Morey, Peter. (2011). "The rules of the game have changed": Mohsin Hamid's The Reluctant Fundamentalist and post-9/11 fiction, Journal of Postcolonial Writing, 47:2, 135-146. Retrieved January 12, 2019, from DOI: $10.1080 / 17449855.2011 .557184$

Morrison, Toni. (1993). Playing in the Dark: Whiteness and the Literary Imagination. New York: Vintage.

Mukherjee, Bharati. "(1996). "Beyond Multiculturalism: Surviving the Nineties." Journal of Modern Literature XX.1, Summer: 29-34.

Mulder, D.C. (1985) "Het vak godsdienstwetenskap," "The Course in Religious Science.' in D.J. Hoens, J.H. Kamstra \& D.C. Mulder (eds.), Introduction to the Study of Religions. pp. 35-40, J.H. Kok, Kampen.

Rocker, Rudolf. (1993). Nationalism and Culture. Black Rose Books. Retrieved November 25th, 2017, from <https://libcom.org/library/nationalism-culture-rudolf-rocker> 
Said Edward. (1979) Orientalism. New York: Vintage Books. Print.

Sheth A. Falguni. (2011). "The War on Terror and Ontopolitics: Concerns with Foucault's Account of Race, Power Sovereignty." Foucault Studies, No. 12: pp. 51-76.

Volkan, Vamik. (1998). "Transgenerational Transmissions and Chosen Traumas. An Element of Large-Group Identity.” Opening Address, XIII International Congress, International Association of Group Psychotherapy. Retrieved July 17, 2018, from www. vamikvolkan.com/Transgenerational- Transmissions-and-ChosenTraumas.php

Walsh, Christopher J. (2009). In the Wake of the Sun: Navigating the Southern Works of Cormac McCarthy. Knoxville: Newfound Press. 